\title{
Динамика содержания хлорофиллов в листьях березы повислой (Betula pendula Roth), произрастающей в парках города Барнаула
}

\section{Dynamics of concentration chlorophylls in the birch leaves (Betula pendula Roth) growing in the city parks in Barnaul}

\author{
Соколова Г. Г., Богатова В. А. \\ Sokolova G. G, Bogatova V. A. \\ Алтайский государственный университет, г. Барнаул, Россия. E-mail: sokolova-gg@mail.ru, bogatova-va@mail.ru
}

Altai State University, Barnaul, Russia

Реферат. В статье рассмотрены результаты биохимических исследований содержания хлорофиллов в листьях берез, произрастающих в парках города Барнаула. В парковых зонах по сравнению с контролем содержание хлорофиллов $a$ и $b$ и отношение $a / b$ ниже. Лучшие условия произрастания берез (сомкнутость крон, удаление от автомагистралей, меньшая частота посещаемости) способствуют увеличению содержания хлорофилла $a$ и $b$ в листьях. Расположение парков вдоль автомагистралей, разреженное расположение деревьев в парке и интенсивное посещение приводят к уменьшению содержания хлорофилла $a$ и $b$ в листьях.

Ключевые слова. Хлорофилл $a$, хлорофилл $b$, фотосинтез, листья березы, техногенное загрязнение.

Summary. The article deals with the results of biochemical studies of chlorophyll content in birch leaves growing in the parks of Barnaul. In city park areas, compared with the control, the content of chlorophyll $a$, chlorophyll $b$ the ratio $a / b$ is lower. The best conditions for the growth of birches (closeness of crowns, distance from highways, lower frequency of attendance) contribute to an increase in the content of chlorophyll $a$ and $b$ in the leaves. The location of the parks along the highways, the sparse location of the trees in the park and the intensive visits lead to a decrease in the content of chlorophyll $a$ in the leaves.

Key words. Chlorophyll $a$, chlorophyll $b$, the birch leaves, technogenic pollution.

\section{Введение}

Древесные растения в городах выполняют средообразующую, санитарно-защитную, рекреационную, эстетическую функции, а их листовые органы способствуют детоксикации газообразных веществ. В условиях мегаполисов растения подвергаются негативному воздействию загрязняющих веществ (выбросы ТЭЦ и промышленных предприятий, отработанные газы автотранспорта), что приводит к нарушению функционального состояния растений.

Высокое содержание хлорофилла а и величина отношения хлорофилла $a / b$, могут служить признаком высокой потенциальной интенсивности фотосинтеза, благоприятных условиях произрастания, более высокой степени защиты мембран хлоропластов от фотоповреждений и большей эффективностью светоусвоения (Николаевский, 1979; Ибрагимова и др., 2010).

Действие поллютантов проявляется прежде всего в изменении биохимического состава, в том числе пигментного комплекса. Изменение содержания пигментов приводит к потере биологической продуктивности, к снижению роста растений (Корнилов, Петухова, 2010).

Сравнительный анализ групп фотосинтетических пигментов в листьях древесных растений в условиях загрязнения атмосферы показал, что характерной реакцией растений на стресс является снижение их количества (Гарифзянов, 2012; Титова, 2013). Атмосферное загрязнение внешней среды является фактором, к которому растения не адаптированы, поэтому накопление в растительных тканях токсинов нарушает структуру и функции ассимиляционного аппарата, наиболее чувствительного к действию токсикантов (Скочилова, Закамская, 2013; Алиева, 2014). 
Высокий уровень загрязнения поллютантами способствует деструкции фотосинтетических пигментов и снижению накопления, а также изменяет соотношение их спектральных форм и структуру мембран хлоропластов, что негативно влияет на фотосинтез, нарушает метаболизм растений и в итоге негативно отражается на росте и развитии растительных организмов. Степень повреждения растений зависит в основном от концентрации токсичного вещества и длительности его воздействия, поэтому только при слабом влиянии наблюдается активизация новообразования пигментов фотосинтеза (Цандекова, Неверова, 2010). Общей реакцией для всех видов растений является разрушение пигментов и снижение содержания хлорофилла под действием токсических веществ. Содержание пигментов изменяется в зависимости от условий произрастания растений. Максимальное содержание хлорофилла $a$ и $b$ регистрируется в более благополучных районах (Кривобочек, 2005).

В Барнауле основными источниками загрязнения являются автотранспорт, а также тепловые электростанции; особенности рельефа способствуют накоплению загрязняющих веществ в листьях растений, произрастающих в разных районах города, поэтому изучение содержания хлорофиллов в древесных растениях имеет важное практическое и теоретическое значение, особенно при проведении экологического мониторинга.

Целью нашей работы явилось изучение содержание хлорофиллов в листьях берез, произрастающих в парках г. Барнаула.

\section{Материалы и методы}

Для оценки содержания фотосинтетических пигментов отбирались листья березы повислой (Betula pendula Roth), произрастающей на территории 5 парков г. Барнаула: парк «Эдельвейс», парк «Юбилейный», парк «Арлекино», парк «Солнечный ветер», парк «Изумрудный». В качестве контроля служили листья березы повислой, произрастающей в районе Южно-Сибирского ботанического сада. В одной точке выбирались не менее 10 деревьев одного возраста и размера с ярко выраженными видовыми признаками, растущими на открытом месте во избежание стрессового влияния затенения (Аношкина, 2005; Ибрагимова, 2006). С каждого дерева из нижней части кроны на уровне поднятой руки с максимального количества доступных веток, направленных условно на север, запад, восток и юг, бралось 20-50 неповрежденных листьев, которые затем высушивались. Сбор растительного материала осуществлялся в период активной вегетации, т.е. июне, июле и августе в середине дня с 10.00 до 15.00 часов, когда содержание пигментов в листьях наибольшее.

Биохимический анализ содержания фотосинтетических пигментов в листьях березы проводился с помощью спектрофотометра марки SHIMADZU UV-1800 в лаборатории кафедры экологии, биохимии и биотехнологии Алтайского государственного университета. Концентрации пигментов (мг/л) в листьях рассчитывались в два этапа по формулам с учетом положения максимумов поглощения пигментов и поправочных коэффициентов на наличие других пигментов и компонентов, рассеивающих свет (Рогожин, 2013).

1 этап. Расчет концентрации пигментов листьев в спиртовом растворе (мг/л):

$\mathrm{C}_{a}=9,784 \mathrm{D}_{662}-0,99 \mathrm{D}_{644}$,

$\mathrm{C}_{b}=21,426 \mathrm{D}_{644}-4,650 \mathrm{D}_{662}$

$\mathrm{C}_{a}+\mathrm{C}_{b}=5,134 \mathrm{D}_{662}+20,436 \mathrm{D}_{664}$

где $\mathrm{D}_{662}$ и $\mathrm{D}_{644}-$ оптическая плотность при длинах волн 662 и 644 нм; $\mathrm{C}_{a}-$ концентрация хлорофилла $a, \mathrm{C}_{b}-$ концентрация хлорофилла $b$, мг/л).

2 этап. Расчет количества пигментов в пробе (мг/100 г):

$\mathrm{C}_{\mathrm{o}}=\mathrm{C} \cdot \mathrm{V} \cdot \mathrm{V}_{2} / \mathrm{m} \cdot \mathrm{V}_{1} \cdot 10(5)$

где $\mathrm{C}$ - концентрация пигмента, мг/л; $\mathrm{V}$ - объем исходной вытяжки, мл; $\mathrm{V}_{1}$ - объем вытяжки, взятой для разбавления, мл; $\mathrm{V}_{2}$ - объем разбавленной вытяжки, мл; $\mathrm{m}$ - масса навески. кин, 1990).

Полученные данные обработаны статистически с использованием t-критерия Стьюдента (Ла- 


\section{Результаты и обсуждение}

Результаты исследований содержания пигментов в листьях берез, произрастающих в разных условиях г. Барнаула, выявили следующие закономерности.

Хлорофилл $\boldsymbol{a}$. На контроле в листьях берез содержание хлорофилла $a$ варьировало от 4,99 до 5,56 мг/100 г, причем резких колебаний концентрации хлорофилла $a$ в течение летних месяцев отмечено не было (табл. 1). В листьях берез, произрастающих в парках г. Барнаула, содержание хлорофилла $a$ по сравнению с контролем достоверно уменьшалось на 24-40 \% и составило 2,99-4,21 мг/100 г. Наибольшее содержание хлорофилла $a$ отмечено в листьях берез, произрастающих в парке «Юбилейный», а наименьшее - в парке «Солнечный ветер». Выявлена тенденция уменьшения содержания хлорофилла $a$ в течение июня-августа по всем паркам города Барнаула.

Таблица 1

Динамика содержания хлорофилла $a$ в листьях берез, произрастающих в парках г. Барнаула

\begin{tabular}{|l|c|c|c|}
\hline \multirow{2}{*}{ Точка отбора проб } & \multicolumn{3}{c|}{ Содержание хлорофилла $a$, мг/100 г } \\
\cline { 2 - 4 } & июнь & июль & август \\
\hline Контроль & $5,20 \pm 0,02$ & $5,56 \pm 0,01$ & $4,99 \pm 0,01$ \\
\hline Парк Юбилейный & $4,00 \pm 0,03$ & $4,21 \pm 0,01$ & $3,87 \pm 0,03$ \\
\hline Парк Изумрудный & $3,51 \pm 0,05$ & $3,62 \pm 0,03$ & $3,01 \pm 0,07$ \\
\hline Парк Эдельвейс & $3,55 \pm 0,05$ & $3,59 \pm 0,08$ & $3,03 \pm 0,04$ \\
\hline Парк Арлекино & $3,61 \pm 0,01$ & $3,70 \pm 0,02$ & $3,11 \pm 0,02$ \\
\hline Парк Солнечный ветер & $3,33 \pm 0,04$ & $3,38 \pm 0,06$ & $2,99 \pm 0,01$ \\
\hline
\end{tabular}

Примечание: $\mathbf{4 , 0 0 \pm 0 , 0 3}$ - значение достоверно при р $<0,05$.

Хлорофилл $\boldsymbol{b}$. Содержание хлорофилла $b$ в листьях берез варьировало на контроле от 2,43 до 2,92 мг/100 г, причем колебаний концентрации хлорофилла $b$ в течение всех летних месяцев не отмечалось (табл. 2). В листьях берез, произрастающих в парках г. Барнаула, содержание хлорофилла $b$ по сравнению с контролем достоверно уменьшается на 7-24 \%. Содержание этого пигмента в листьях берез варьирует от 1,85 до 2,73 мг/100 г. Наибольшее содержание хлорофилла $b$ в листьях берез отмечено в парке «Юбилейном», наименьшее - в листьях берез, произрастающих в парке Солнечный ветер. В динамике по месяцам во всех парках города Барнаула отмечена тенденция небольшого увеличения содержания хлорофилла $b$ в июле и незначительного снижения его содержания в августе (табл. 2).

Таблица 2

Динамика содержания хлорофилла $b$ в листьях берез, произрастающих в парках г. Барнаула

\begin{tabular}{|l|c|c|c|}
\hline \multirow{2}{*}{ Точка отбора проб } & \multicolumn{3}{c|}{ Содержание хлорофилла $b$, мг $/ 100$ г } \\
\cline { 2 - 4 } & июнь & июль & август \\
\hline Контроль & $2,88 \pm 0,01$ & $2,92 \pm 0,01$ & $2,43 \pm 0,04$ \\
\hline Парк Юбилейный & $2,64 \pm 0,01$ & $2,73 \pm 0,03$ & $2,34 \pm 0,02$ \\
\hline Парк Изумрудный & $2,39 \pm 0,01$ & $2,45 \pm 0,01$ & $1,99 \pm 0,03$ \\
\hline Парк Эдельвейс & $2,30 \pm 0,03$ & $2,37 \pm 0,01$ & $1,87 \pm 0,04$ \\
\hline Парк Арлекино & $2,31 \pm 0,02$ & $2,46 \pm 0,01$ & $1,98 \pm 0,01$ \\
\hline Парк Солнечный ветер & $2,29 \pm 0,04$ & $2,37 \pm 0,02$ & $1,85 \pm 0,01$ \\
\hline
\end{tabular}

Примечание: $\mathbf{2 , 6 4} \pm \mathbf{0 , 0 1}$ - значение достоверно при $\mathrm{p}<0,05$.

Отношение хлорофиллов $\boldsymbol{a} / \boldsymbol{b}$. Нами подсчитано отношение хлорофиллов $a / b$ в листьях берез, произрастающих в г. Барнауле, как показателя потенциальной фотохимической активности листьев. Листья берез, произрастающих в парках г. Барнаула, подвергаются воздействию техногенного загрязнения, поэтому отношение хлорофиллов $a / b$ снижается по сравнению с контролем в среднем на $20 \%$ (табл. 3). В динамике по месяцам достоверно значимых различий не обнаружено. Изменения отноше- 
ния хлорофиллов $a / b$ свидетельствуют о перестройках ультраструктуры тканей листьев, в первую очередь, тиллакоидов стромы или гран.

Таблица 3

Отношение хлорофиллов $a / b$ в листьях берез, произрастающих в парках г. Барнаула

\begin{tabular}{|l|c|c|c|}
\hline \multirow{2}{*}{ Точка отбора проб } & \multicolumn{3}{c|}{ Отношение хлорофиллов $a / b$} \\
\cline { 2 - 4 } & июнь & июль & август \\
\hline Контроль & 1,81 & 1,90 & 2,05 \\
\hline Парк Юбилейный & 1,52 & 1,54 & 1,65 \\
\hline Парк Изумрудный & 1,47 & 1,48 & 1,51 \\
\hline Парк Эдельвейс & 1,54 & 1,51 & 1,62 \\
\hline Парк Арлекино & 1,56 & 1,50 & 1,57 \\
\hline Парк Солнечный ветер & 1,45 & 1,43 & 1,62 \\
\hline
\end{tabular}

Таким образом, наблюдается достоверное закономерное снижение содержания хлорофилла $a$, хлорофилла $b$ и отношения хлорофиллов $a / b$ в парках г. Барнаула по сравнению с контролем. Лучшие условия произрастания (наличие большей сомкнутости крон, удаление от автодорог, меньшая частота посещаемости) способствуют увеличению содержания хлорофилла $a$ и $b$ в листьях березы (парк Юбилейный), а изменение этих условий, проявляющееся в расположении вдоль автомагистралей, разреженном расположении деревьев и интенсивном посещении, приводит к уменьшению содержания хлорофилла $a$ (парк Солнечный ветер).

\section{ЛИТЕРАТУРА}

Алиева М. Ю. Изучение параметров флуоресценции хлорофилла древесных растений в условиях различной транспортной нагрузки // Известия Самарского научного центра РАН, 2014. - №1 - С. 701-703.

Аношкина Л. В. Чем дышит промышленный город. - С.: Гидрометеоиздат, 2005. - С. 44-49.

Гарифзянов $\boldsymbol{A}$. P. Образование перекиси водорода и появление окислительного стресса в листьях древесных растений в условиях промышленного загрязнения // Фундаментальные исследования, 2012. - № 1. - С. 151-155.

Ибрагимова С.С., Горелова В.В., Кочетов А.В., Шумный В.К. Роль различных метаболитов в формировании стрессоустойчивости растений // Вестник Новосибирского государственного университета, 2010. - № 3. - Т. 8. C. $98-103$.

Корнилов А. Л., Петухова Г. А. Влияние накопления тяжелых металлов на содержание пигментов фотосинтеза растений из прибрежной зоны водоемов г. Тюмени // Экология, 2010. - № 5. - С. 190-196.

Кривобочек В. Г. Биохимическая оценка газоустойчивости декоративных кустарников (на примере г. Балашова). Автореф. дис. ... канд. биол. наук. - Томск, 2005. - 19 с.

Лакин Г. Ф. Биометрия. - М.: Высшая школа, 1990. - С. 350-352.

Неверова О. А., Быков А. А. Оценка адаптивного потенциала Betula pendula Roth. В условиях преобладающего влияния выбросов промзоны г. Кемерово // Сибирский экологический журнал, 2013. - №. 2. - С. 24-27.

Николаевский В. С. Биологические основы газоустойчивости растений // Наука, 1979. - №5. - С.22-28.

Рогожсин В. В. Практикум по биохимии. - СПб.: Лань, 2013. - С. 344-356.

Скочилова $\boldsymbol{E}$. A., Закамская $\boldsymbol{E}$. $\boldsymbol{C}$. Изучение биохимических показателей Betula pendula Roth. в условиях городской среды // Известия Самарского научного центра РАН, 2013. - № 3. - С. - 782-784.

Tumoвa M. C. Реакция пигментной системы сосны обыкновенной (Pinus sylvestris L.). На загрязнение окружающей среды // Вестник Красноярского государственного аграрного университета, 2013. - № 10. - С. 122-126.

Цандекова О. Н., Неверова О. А. Влияние выбросов автотранспорта на пигментный комплекс листьев древесных растений // Известия Самарского научного центра Российской академии наук, 2010. - № 1. - С. 853-856. 